\title{
PENGELOLAAN MEDIA PEMBELAJARAN SEKOLAH DASAR
}

\author{
Eny Munisah ${ }^{1}$ \\ Enymuni0@gmail.com
}

\section{Universitas Muhammadiyah Kotabumi}

\begin{abstract}
Management of learning media is a part of efforts to improve the quality of education. As for the indicators that must be considered in the management of learning media especially: planning instructional media, organizing media, learning media management, evaluating media. Of the school, it is expected that the preparation of media programs can run effectively with the learning programs that have been made so that it can contribute positively to learning. The learning media management process must go hand in hand with school programs, it is necessary to manage a management of learning media in elementary school that is responsible for administering all activities related to learning media management, understanding of media management is important for the officer in planning media programs, classification of media, the grouping of media based on the condition of each school or based on certain subjects so that the media can be used optimally in the classroom or in out door class. Supervision should be carried out programmatically by the school principal and personnel at the relevant agencies of the district and district level offices are expected to be input of increasing the development of learning media management in the next year.
\end{abstract}

\section{Key words: management, learning media, elementary school}

\begin{abstract}
Abstrak: Manajemen media pembelajaran adalah bagian dari upaya meningkatkan kualitas pendidikan. Adapun indikator yang harus diperhatikan dalam pengelolaan media pembelajaran adalah: perencanaan media pembelajaran, pengorganisasaian media, pengelolaan media, dan evaluasi media. Di sekolah diharapkan persiapan program media dapat berjalan efektif dengan program pembelajaran yang telah dibuat sehingga dapat berkontribusi positif bagi pembelajaran. Proses manajemen media pembelajaran harus berjalan seiring dengan program sekolah, perlu untuk mengelola manajemen media pembelajaran di sekolah dasar yang bertanggung jawab untuk mengelola semua kegiatan yang berkaitan dengan manajemen media pembelajaran, pemahaman tentang manajemen media penting bagi petugas dalam merencanakan program media, klasifikasi media, pengelompokan media berdasarkan kondisi masing-masing sekolah atau berdasarkan mata pelajaran tertentu sehingga media dapat digunakan secara optimal di ruang kelas atau di luar kelas. Pengawasan harus dilakukan secara terprogram oleh kepala sekolah dan personel di dinas terkait di tingkat kabupaten dan kabupaten diharapkan menjadi masukan untuk meningkatkan pengembangan manajemen media pembelajaran di tahun berikutnya.
\end{abstract}

Kata kunci: manajemen, media pembelajaran, sekolah dasar

\section{PENDAHULUAN}

Terjadinya guru dan tenaga

kependidikan lain yang cakap dalam

mengelola dan memanfaatkan media pembelajaran dapat mencegah terjadinya aktivitas belajar mengajar yang bersifat verbal karena siswa hanya menerima materi dari informasi yang dilambangkan dengan 
kata-kata oleh ceramah guru sebagai sumber belajar tunggal. Akibatnya akan terjadi verbalisme artinya siswa dapat menyebutkan kata-kata, tetapi tidak mengerti arti/maksud kata tersebut. Hal ini sering terbukti setelah guru memberikan penjelasan melalui ceramah kemudian mengajukan pertanyaan, ternyata sebagian besar siswa tidak dapat menjawab pertanyaan guru dengan memuaskan. Hambatan komunikasi tersebut akan berpengaruh pada pencapaian kompetensi yang telah ditetapkan sebelumnya.

Peningkatan kualifikasi sekolah pendidik dituntut memiliki pengetahuan yang cukup, mampu menyampaikan dan mempunyai sikap yang dapat dicontoh oleh siswa, serta keterampilan yang dimiliki secara holistik dapat bermanfaat dalam dunia pendidikan. Termasuk di dalamnya mampu mengelola media pembelajaran, sehingga pembelajaran dapat diberdayakan terhadap komponen pembelajaran yang dilimiki sekolah. Keterampilan serta pengalaman yang dimiliki oleh seorang pendidik dalam mengikuti pelatihan, diharapkan dapat menindaklanjuti sehingga memberi kontribusi positif pada kemampuan guru dalam melaksanakan tugas pembelajaran dan mengelola seluruh komponen pembelajaran secara efektif.

Kendala yang sering dihadapi para guru Sekolah Dasar adalah tugas sebagai guru kelas yang harus bertanggung jawab dan merencanakan media pembelajaran tersebut dituntut sebagai fasilitator mediator dalam proses pembelajaran. Hal ini dengan tujuan untuk mengoptimalkan pengelolaan dan pemanfaatan media pembelajaran, serta upaya pengembangan pengetahuan, ketrampilan, sikap guru untuk meningkatkan kualifikasi profesionalnya.

Kepala sekolah sebagai salah satu komponen utama proses manajerial sekolah berfungsi sebagai pelopor di sekolah tersebut. Oleh karena itu kepala sekolah berkewajiban memotivasi, memonitoring serta mengevaluasi jalannya program sekolah, baik yang bersifat edukatif yang berhubungan dengan pengajaran maupun administrasi yang berkaitan dengan pengelolaan sekolah. Tugas tersebut sebagai satuan pendidikan yang ada dibawah tanggungjawabnya. Dengan kemampuan mempengaruhi, mendorong, membimbing, mengarahkan dan menggerakkan guru, staf dan siswa untuk bekerja atau berperan guna mencapai tujuan yang ditetapkan bersama. Sehingga diharapkan dapat menciptakan budaya sekolah yang kondusif dan mampu memotivasi para guru untuk senantiasa meningkatkan profesionalisme kerjanya dengan mengembangkan seluruh komponen pembelajaran secara maksimal, termasuk di dalamnya pengelolaan dan penggunaan media dalam pembelajaran. 


\section{MEDIA PEMBELAJARAN}

\section{a. Pengertian Media Pembelajaran.}

Wibawa (2010) media adalah semua saluran pesan yang dapat digunakan sebagai sarana komunikasi dari seseorang ke orang lain yang tidak ada dihadapannya. Jadi media menunjukkan segala sesuatu yang dapat digunakan untuk menyalurkan pesan dari pengirim ke penerima sehingga dapat merangsang pikiran, perasaan, perhatian, dan minat penerima pesan. Dengan kata lain medium (jamak, media) merupakan perantara komunikasi yang mengantar informasi antara sumber dan penerima. Jadi film, televisi, diagram, foto, radio, rekaman audio, gambar yang diproyeksikan, bahanbahan cetakan, komputer, dan sejenisnya adalah media komunikasi. Apabila media itu membawa pesan-pesan atau informasi materi yang akan disampaikan mempunyai tujuan instruksional atau mengandung maksud-maksud pembelajaran, maka media itu disebut media pembelajaran.

Wibawa (2010) media pembelajaran adalah alat penyalur pesan pembelajaran yang dapat menumbuhkan imajinasi seseorang, perbuatan dan mendorong siswa dalam proses pembelajaran untuk membantu pencapaian proses belajar.

Dalam kegiatan belajar mengajar sering pula pemakaian kata media pembelajaran digantikan dengan istilah seperti alat pandang dengar, bahan pengajaran, komunikasi pandang dengar, pendidikan alat peraga pandang, teknologi pendidikan, alat peraga dan media penjelas. Konsep media juga sangat erat hubungannya dengan istilah alat bantu belajar. Pada dasarnya semua istilah tersebut dapat dimasukkan dalam konsep media, karena konsep media merupakan perkembangan dari konsep tersebut.

Rahardi (2013) media pembelajaran adalah istilah sumber belajar. Sumber belajar mempunyai cakupan yang lebih luas, dalam arti luas sumber belajar adalah segala daya yang dapat dimanfaatkan untuk kepentingan proses belajar mengajar baik secara langsung maupun tidak langsung. Begitu banyaknya konsep yang berhubungan erat dengan media pembelajaran seperti media pendidikan, sumber belajar, alat peraga, alat bantu belajar, sehingga dalam penulisan ini lebih menekankan pada media pembelajaran yang berupa media audio, visual, audio visual, dan media lain selain pembukuan yang di Sekolah Dasar biasanya dikelola dalam kegiatan perpustakaan sekolah.

\section{b. Klasifikasi Media.}

Sadiman, dkk. (2010) pengertian media adalah bahan peralatan lunak yang berisi pesan atau informasi pendidikan yang biasanya disajikan dengan mempergunakan peralatan. Dengan masuknya berbagai pengaruh ke dalam khazanah pendidikan seperti ilmu cetak mencetak, tingkah laku, komunikasi dan laju perkembangan 
teknologi elektronik, media dalam perkembangannya tampil dalam berbagai jenis dan format (modul cetak, film, televisi, film bingkai, film rangkai, program radio, komputer dll).

Rahardi (2013) tujuan penggunaan perangkat media, media pendidikan terdiri atas: head fare yang berfungsi sebagai alat penampil, yaitu projektor slide. Sofe fare yaitu program yang ditampilkan, misal: slide, kaset, CD, dan plastik transparansi.

Dalam buku penyelenggaraan pendidikan di Sekolah Dasar (Depdikbud, 2011) dijelaskan bahwa sarana prasarana pendidikan ditinjau dari fungsinya dikelompokkan menjadi:

1) Perangkat fisik, berupa bangunan sekolah seperti ruang kelas, ruang guru, ruang kepala sekolah, gudang,dan sebagainya; perabot sekolah seperti meja, kursi, papan tulis, almari, dan sebagainya, sarana tata usaha pendidikan seperti, buku induk siswa, buku rapor, peralatan kantor dan sebagainya.

2) Media pendidikan, yaitu perangkat keras, yaitru segala jenis alat penampilan elektronik yang digunakan untuk menyampaikan pesan dalam belajar mengajar, seperti projektor, televisi, komputer, perangkat lunak seperti program yang ditampilkan atau segala jenis materi pengajaran yang disampaikan melalui alat penampil dalam kegiatan belajar mengajar.

3) Alat peraga dan praktik yaitu alat yang diperagakan atau dipertunjukkan dalam kegiatan belajar mengajar yang berfungsi sebagai sarana untuk memperjelas konsep, alat praktik bertujuan supaya memiliki keterampilan sebagai sarana penunjang dalam laboratorium.

4) Administrasi sekolah, meliputi segala masalah yang berhubungan dengan informasi baik internal maupun external yang berkaitan dengan lingkungan pendidikan di sekolahnya.

Pengelompokkan media sebagaimana tersebut di atas bermacam-macam, pada dasarnya pengelompokkan yang telah dilakukan tersebut bertujuan untuk memberi kemudahan para pengguna media dalam memanfaatkan media dan bagi para petugas. Sehingga dalam mengelola media pembelajaran dapat memberi masukkan yang positif, dapat dimanfaatkan dengan baik dalam pembelajaran, dapat meletakkan dasar yang konkret untuk berfikir, memberi gambaran nyata, sebagai kegiatan keterampilan siswa baik di dalam maupun di luar sekolah, dalam pencapaian proses pembelajaran yang berlaku

\section{c. Karakteristik Media.}

Usaha pengklarifikasian media di atas mengungkapkan bahwa karakteristik atau 
ciri khas suatu media berbeda menurut tujuan atau maksud pengelompokkannya.

Sudjana (2012) beberapa jenis media yang lazim dipakai dalam kegiatan belajar mengajar khususnya di sekolah dasar, diantaranya adalah:

1) Media grafis; gambar, diagram, peta dan globe.

2) Media audio; radio, alat perekam pita magnetik, laboratorium bahasa.

3) Media proyeksidiam; film bingkai, film rangkai, transparansi, mikrofis, film, permainan dan simulasi.

\section{d. Manfaat Media Pembelajaran.}

Penerapan media pembelajaran dalam proses pembelajaran menunjukkan ada perbedaan yang signifikan hasil belajar yang diperoleh siswa dengan menggunakan media

Hamalik (2014) media dapat digunakan untuk kegiatan pembelajaran sebagai berikut.

1) Menarik perhatian. Sebuah gambar dilayar, pertanyaan di papan tulis, atau musik yang mengalun ketika siswa masuk ke ruang kelas dapat digunakan untuk menarik perhatian siswa.

2) Mengingat kembali. Gunakan media untuk membantu siswa mengingat apa yang telah mereka pelajari, sehingga materi baru dapat dikaitkan dan ditambahkan pada materi lama.

3) Menyampaikan tujuan kepada siswa.
4) Menyampaikan isi/materi pelajaran baru. Media tidak hanya dapat membantu membuat materi baru mudah diingat, tetapi juga membantu menyampaikan materi baru.

5) Mendukung pembelajaran melalui contoh dan perluasan pandangan. Salah satu keuntungan dari media adalah membawa dunia ke dalam kelas, jika memungkinkan membawa siswa ke dalam dunia itu.

6) Mendapatkan respon siswa. Menyampaikan informasi dan memberi pertanyaan menciptakan keterlibatan dalam menjawab pertanyaan.

7) Memberikan umpan balik/feedback.

8) Meningkatkan ingatan dan transfer. Gambar meningkatkan ingatan, media membantu memvisualisasikan pelajaran dan mentransfer konsep-konsep abstrak menjadi konkret sehingga lebih mudah mengingat objek.

9) Menilai kinerja. Media adalah cara yang luar biasa untuk mengadakan penilaian.

Bertitik tolak dari beberapa kegunaan media pembelajaran jelaslah bahwa media pembelajaran merupakan dasar yang sangat diperlukan yang bersifat melengkapi dan merupakan bagian integral dengan berhasilnya proses pendidikan dan usaha pengajaran di sekolah.

Disamping itu kegunaan media pembelajaran dapat membangkitkan minat 
yang baru, melalui alat/media para siswa akan memperoleh pengalaman, lebih luas dan lebih kaya. Dapat memotivasi kegiatan belajar serta memberikan pengaruh psikologis terhadap siswa. Memberikan konsep yang sebenarnya secara realistik dan teliti. Memberikan pengalaman yang menyeluruh dari yang kongkrit sampai yang abstrak.

\section{PEMBAHASAN.}

\section{a. Konsep Pengelolaan.}

Fattah (2010) pengelolaan diambil dari bahasa Inggris management yang mengandung arti ketatalaksanaan/pengelolaan. Managemen sering diartikan sebagai ilmu, kiat, profesi. Dikatakan sebagai ilmu karena manajenen dipandang sebagai suatu bidang pengetahuan yang secara sistematis berusaha memahami mengapa dan bagaimana orang bekerja sama. Dikatakan sebagai kiat karena manajemen mencapai sasaran melalui cara-cara dengan mengatur orang lain menjalankan dalam tugas.

Manajemen sebagai proses merencanakan, mengorganisasi, memimpin, dan mengendalikan upaya organisasi dengan segala aspeknya agar tujuan organisasi tercapai secara efektif dan efesien.

Fattah (2010) fungsi manajemen adalah sebagai berikut.

1) Perencanaan (planing) adalah suatu kegiatan dengan langkah-langkah memprediksi sesuatu, menetapkan tujuan, menginterpretasikan tujuan, mengembangkan program untuk mencapai sasaran, menyusun jadwal, mengembangkan prosedur pelaksanaan, menyiapkan anggaran, dan menetapkan standar keberhasilan.

2) Pengorganisasian (organizing) merupakan kegiatan yang meliputi menyusun struktur organisasi, pendelegasian dan penyerahan tanggung jawab, pemanfaatan sumber daya yang ada, pembagian tugas tentang pekerjaan dan mengembangkan deskripsi tentang tugas.

3) Pengarahan (directing) merupakan salah satu fungsi manajemen meliputi kegiatan: memberikan motivasi atau dorongan kepada karyawan atau anggota,melakukan koordinasi terhadap anggota organisasi, melakukan komunikasi dan memberikan penilaian terhadap kinerja yang telah dilakukannya.

4) Pengendalian (controlling) merupakan kegiatan pengawasan yang bertujuan memberikan penilaian dan evaluasi meliputi, kegiatan mengevaluasi pelaksanaan program, melakukan tindakan korektif, menilai keberhasilan yang ada, memonitor pelaksanaan program dan melakukan pelaporan sebagai pertimbangan program yang berkesinambungan. 
Dengan kata lain dapat dikemukakan bahwa manajemen adalah bahwa manajemen adalah rangkaian aktivitas dari merencanakan dan pengambilan keputusan, pengorganisasian, memimpin dan pengendalian organisasi manusia, keuangan, fisik dan informasi sumber daya untuk mencapai tujuan organisasi secara efisien dan efektif.

\section{b. Proses Pengelolaan Media Pembelajaran Sekolah Dasar.}

Personal perencanaan kegiatan media melibatkan Kepala Sekolah, guru, dan komite sekolah. Perencanaan kegiatan tersebut disesuaikan dengan kebutuhan siswa dengan asumsi bahwa guru adalah personal yang paling utama terhadap media menjadi tanggung jawab para guru. Guru mendapat keleluasaan untuk menyusun program media dan menentukan media yang akan digunakan.

Pemanfaatan media pembelajaran akan memberi kesempatan dan kemampuan para guru maupun siswa untuk berkreasi menciptakan media dan akan memberi kesan tersendiri terutama para guru dalam menyampaikan materi pelajaran, siswa mudah mencerna konsep yang diterimanya. Penggunaan media pembelajaran juga memungkinkan pembelajaran berlangsung lebih sistematis, teratur dan dipersiapkan secara lebih baik oleh guru. Oleh karena itu pengelolaan media pembelajaran mutlak diperlukan.
Mulyasa (2013) pengelolaan media pembelajaran merupakan bagian integral pengelolaan sekolah. Pengelolaan media pembelajaran di Sekolah Dasar menjadi tugas personil di Sekolah yang bersangkutan, baik kepala sekolah, guru kelas, guru mata pelajaran, atau karyawan yang diberi tugas untuk mengelola media pembelajaran agar dapat memberi kemanfaatan proses belajar mengajar demi meningkatkan mutu pembelajaran. Proses pengelolaan media pembelajaran tersebut secara garis besar meliputi perencanaan, pengorganisasian, pelaksanaan pengelolaan, dan evaluasi terhadap pengelolaan media pembelajaran. Mulyasa (2013) pembahasan lebih lanjut dapat diungkapkan sebagai berikut.

\section{1) Perencanaan Media Pembelajaran.}

Penyusunan program kegiatan media pembelajaran sangat penting dibuat untuk menentukan kegiatan yang akan dilakukan selama kurun waktu tertentu, misalnya satu tahun. Kegiatan ini sangat membantu dalam mengatur jadwal penggunaan media serta persiapan alat/bahan yang diperlukan.

Merencanakan dana kegiatan operasional, perawatan/perbaikan, dan pengadaan media pembelajaran sesuai dengan kebutuhan siswa merupakan salah satu bagian dari perencanaan media pembelajaran sekolah. Perencanaan kegiatan media disesuaikan dengan kebutuhan siswa dengan asumsi bahwa guru adalah personal 
yang paling utama terhadap media menjadi tanggung jawab para guru, guru mendapatkan keleluasaan untuk menyusun program media dan menentukan media apa yang akan digunakan. Penggunaan media pembelajaran di dalam kelas harus direncanakan dengan sebaik-baiknya, meskipun dalam merencanakan penggunaan media pembelajaran tersebut guru diberi keleluasaan untuk memilih dan mengembangkan media pembelajaran sesuai dengan potensi, kebutuhan dan kemampuan peserta didik, serta kebutuhan masysrakat disekitar sekolah. Oleh karena itu guru harus dapat memahami, menerjemahkan dan menjabarkan isi kurikulum yang akan ditransformasikan kepada peserta didik, karena kurikulum dapat digunakan sebagai perantara bagi guru dan peserta didik dalam proses pengalihan atau transformasi yang berlangsung melalui sebuah kegiatan yang disebut pembelajaran. Dalam proses pembelajaran ini terjadi interaksi antara peserta didik dengan seluruh komponen pembelajaran.

\section{2) Pengorganisasian Media Pembelajaran.}

Pengorganisasian adalah pengelola/ pengurus media pembelajaran yang terdiri dari kepala sekolah, petugas media pembelajaran, dan kelompok jabatan fungsional. Pentingnya pengelolaan media untuk dilakukan, yang menitikberatkan pada aspek administrasi siswa, ketenagaan, sarana prasarana, pembiayaan, dan peran serta masyarakat. Program peningkatan kualitas proses belajar mengajar dengan mengoptimalkan pemanfaatan media dalam pembelajaran, kesediaan media berupa alat peraga mata pelajaraan yang sesuai dengan jenjang kelas dan materi pembelajaran disetiap kelas, pembagian waktu penggunaan media pembelajaran yang disesuaikan dengan jadwal pelajaran, serta aktifitas dan prosedur penggunaan media dilaksanakan sesuai dengan ketentuan yang telah ditetapkan.

Berkenaan dengan pengelolaan media pembelajaran, hasil kegiatan pengelolaan organisasi ini berupa profil bentuk struktur atau susunan organisasi, baik susunan organisasi eksternal maupun internal. Susunan organisasi eksternal menggambarkan struktur organisasi pengelola media pembelajaran, sedang susunan organisasi internal menggambarkan bagian/bidang yang ada dalam pengelolaan media pembelajaran, hubungan tata kerja, tugas dan fungsi masing-masing bagian/bidang.

Orang-orang yang terlibat langsung dalam pengelolaan media pembelajaran secara umum adalah kepala sekolah, penanggung jawab teknis kegiatan sesuai dengan bidang masing-masing. 


\section{3) Pelaksanaan Pengelolaan Media Pembelajaran.}

Kegiatan pelaksanaan pengelolaan media pembelajaran meliputi: pengadmnistrasian media pembelajaran, memilih dan menyiapkan media yang akan digunakan, menggunakan media dalam pembelajaran, serta mengatur/menata media pembelajaran.

\section{4) Evaluasi Pengelolaan Media Pembelajaran.}

Petugas/pengelola media bertanggungjawab atas segala kegiatan manajemen media pembelajaran. Kegiatan evaluasi dan pelaporan merupakan kewajiban yang harus dilakukan setiap pelaku manajemen media pembelajaran di sekolah. Dengan melakukan evaluasi akan dapat mengetahui ketercapaian program yang telah dirumuskan. Hasil evaluasi ini dapat dijadikan tolok ukur keberhasilan sekaligus mengungkap kekurangan selama proses berlangsung yang dapat digunakan sebagai bahan masukan, pertimbangan, dan pedoman dalam menyusun program media pada tahun berikutnya.

Monitoring/pengawasan hendaknya dilakukan secara terprogram oleh kepala sekolah dan personal pada instansi terkait dari Dinas di tingkat kecamatan dan kabupaten untuk mengungkap temuantemuan, faktor penghambat, dan kondisi yang diharapkan agar dapat dijadikan sebagai masukan untuk menentukan langkah kerja dan pengembangan pengelolaan media pembelajaran agar intensitas penggunaan media dalam pembelajaran demi peningkatn mutu pendidikan dapat terwujud.

Dengan demikian diharapkan evaluasi dapat menghindari terjadinya penyimpangan-penyimpangan untuk menjamin tercapainya tujuan karena dengan melakukan evaluasi akan memperoleh fakta bagi yang biasa dijumpai serta kondisi yang diharapkan tentang media pembelajaran baik ditinjau dari aspek keberadaan media, pengelola media, maupun pengelolaan media pembelajaran.

Pada akhirnya kegiatan evaluasi dapat menyediakan informasi dasar guna merancang ulang program yang dilaksanakan sekaligus perolehan informasi yang berharga untuk perumusan dan perancangan kembali suatu program maupun pengambilan keputusan yang akhirnya dapat meningkatkan kinerja guru dalam mengelola media pembelajaran.

\section{SIMPULAN}

Pengelolaan media pembelajaran sebagai bagian dari upaya meningkatkan kualitas pendidikan. Adapun indikator yang harus diperhatikan dalam pengelolaan media pembelajaran khusus di Sekolah Dasar adalah:

1) Perencanaan media pembelajaran merupakan bagian integral dari program sekolah untuk itu perlu melibatkan 
seluruh komponen sekolah, baik personal intern maupun ekstern sekolah, diharapkan penyusunan program media dapat berjalan searah dengan program pembelajaran yang telah dibuat sehingga dapat memberi kontribusi positif terhadap pembelajaran.

2) Proses pengelolaan media pembelajaran harus berjalan seiring dengan program sekolah, perlu dibentuk kepengurusan/ pengelola media pembelajaran di SD yang bertanggung jawab dalam mengadministrasian semua kegiatan yang berkaitan dengan pengelolaan media pembelajaran.

3) Pemahaman dan pengetahuan tentang pengelolaan media penting bagi petugas dalam merencanakan program media, pengklasifikasian media, pengelompokan media berdasarkan kondisi sekolah masing-masing atau berdasarkan mata pelajaran tertentu agar media dapat digunakan secara optimal di dalam kelas maupun di tempat penyimpanan.

4) Monitoring/pengawasan hendaknya dilakukan secara terprogram oleh kepala sekolah dan personil pada instansi terkait dari dinas di tingkat kecamatan dan kabupaten diharapkan sebagai bahan masukan peningkatan pengembangan pengelolaan media pembelajaran pada tahun berikutnya.

\section{DAFTAR RUJUKAN}

Depdikbud, (2011). Penyelenggaraan Pendidikan di SD. Jakarta: Depdagri, Ditjen Pemerintahan Umum dan Otonomi Daerah.

Fattah Nanang, (2010). Landasan Manajemen Pendidikan. Bandung: PT Remaja Rosdakarya.

Hamalik Oemar, (2014). Media Pendidikan. Bandung: PT Citra Abditya Bakti.

Mulyasa, (2013). Manajemen Berbasis Sekolah Konsep, Strategi, dan Implementasi. Bandung: PT Remaja Rosdakarya.

Rahardi Aristio, (2013). Media Pembelajaran. Jakarta: Depdiknas, Dirjen Dikdasmen Direktorat Tenaga Kependidikan.

Sadiman Arief S., dkk., (2010). Media Pendidikan Pengertian Pengembangan dan Pemanfaatan. Jakarta: CV Rajawali.

Sudjana Nana, (2012). Media Pengajaran. Bandung: CV Sinar Baru Algesindo.

Wibawa Basuki, (2010). Media Pengajaran. Jakarta: Depdikbud Ditjen Dikti PPTK. 